\title{
ASSESSMENT OF ENERGY EFFICIENCY OF HIGH-VOLTAGE LUE MODULATORS
}

\author{
O.I. Kosoy, V.O. Matz, V.P. Romasko, Yu.A. Titarenko, V.Yu. Tytov, D.V. Titov, Yu.D. Tur, \\ I.O. Chaika, I.A. Chertishchev, E.A. Yaroshenko \\ National Science Center "Kharkov Institute of Physics and Technology", Kharkiv, Ukraine \\ E-mail: tur@kipt.kharkov.ua
}

An assessment of the energy efficiency of pulse modulators of technological accelerators at the NSC KIPT. The influence of the parameters of a pulse transformer on a voltage pulse at a load is investigated. The possibilities of increasing the energy efficiency of plants are considered. Studies of losses in high-voltage pulse modulator systems were conducted and it was shown that the main elements that require replacement or improvement are forming lines and pulse transformers.

PACS: $29.17+\mathrm{w}$

\section{INTRODUCTION}

Energy efficiency is one of the most important parameters of technological accelerators and is determined by the conversion efficiency in its systems. [1] The system of pulsed high-voltage power klystrons belongs to the most energy-intensive. The basis of its creation is a linear scheme of a high-voltage modulator with a resonant charge of the forming line and its subsequent discharge through a thyratron switch to a pulse transformer of high-voltage power amplifying klystrons [2].

Optimization of parameters of all elements, matching of wave resistances, reduction of stray fields in a pulse transformer, capacitors own inductance and adjustment of forming lines during its manufacture of a modulator ensures pulse formation efficiency over $80 \%$ with full efficiency conversion up to $70 \%$. In the process of long-term operation, due to the degradation of the properties of the elements, the optimization conditions are violated and leading to reduced energy efficiency. This paper presents preliminary data on the assessment of changes in the energy efficiency of high-voltage modulators during their long-term operation. The effect of changing the parameters on the efficiency of the formation is considered and the energy losses in the modulator nodes are estimated.

\section{EXPERIMENTAL INSTALLATION}

Existing modulators operate according to a standard linear circuit with a resonant charge of a single forming line followed by discharge through a thyratron switch and a pulse transformer with a transformation ratio of $\mathrm{n}=13$. The load is a klystron (KIU-12) with a beam resistance of $1700 \mathrm{Ohms}$.

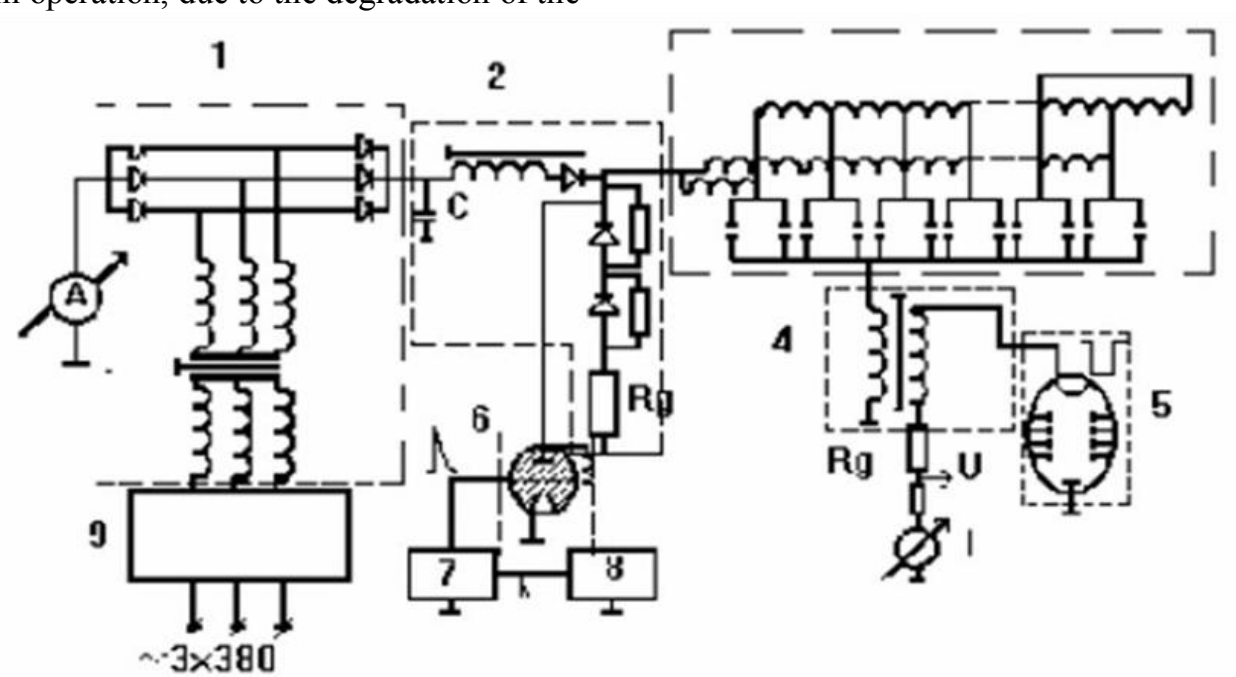

Fig. 1. Block diagram of the klystron modulator:

1 -transformer-rectifier; 2 - charging circuit; 3 -forming line; 4 -pulse transformer; 5 -klystron; 6-thyratron; 7, 8 - triggering pulse amplifiers thyratron; 9 - voltage regulator

Three-phase alternating voltage, supplied to a stepup transformer connected to a rectifier, is regulated by a thyristor regulator. The rectified voltage (up to $35 \mathrm{kV}$ ), proportional to the input, is fed to the forming line through a charging inductor with an inductance $\mathrm{L}=32 \mathrm{H}$. The forming line consists of 10 capacitors $(\mathrm{C}=0.03 \mu \mathrm{F}) \quad$ connected by variable inductances $(\mathrm{L} \approx 2 \mu \mathrm{H})$. The characteristic resistance of the forming line is 8 Ohms.
We use thyratrons of the type TGI-2500/50 (TGI$5000 / 50)$ to discharge the PFN on a pulse transformer. As you know, the most important elements that determine the efficiency of the formation of the pulse shape in the linear circuit of the VR modulator is the pulse forming network (PFN) and the pulse transformer [3]. At the same time, a prerequisite is the coordination of wave impedances and the possibility of operation of elements at high average powers. The efficiency of 
high-voltage pulse modulators is determined by two main factors: thermal losses in the modulator systems and the level of pulse formation closest to rectangular (formation efficiency) [4].

\section{INFLUENCE OF A PULSE TRANSFORMER ON A VOLTAGE PULSE FORM}

The main way to reduce heat loss in a pulse transformer is to use magnetic materials with a low coercive force, having high resistivity and high saturation induction, and therefore dial a magnetic system from a tape of small thickness. The main requirement for a pulse transformer is to ensure sufficiently small distortions in the shape of the pulses to which they are transmitted. These distortions are due to the influence of the inductance of the primary winding, the leakage inductance and the capacitance of the transformer windings. Therefore, special attention is paid to the shape of the impulse and methods for its correction.

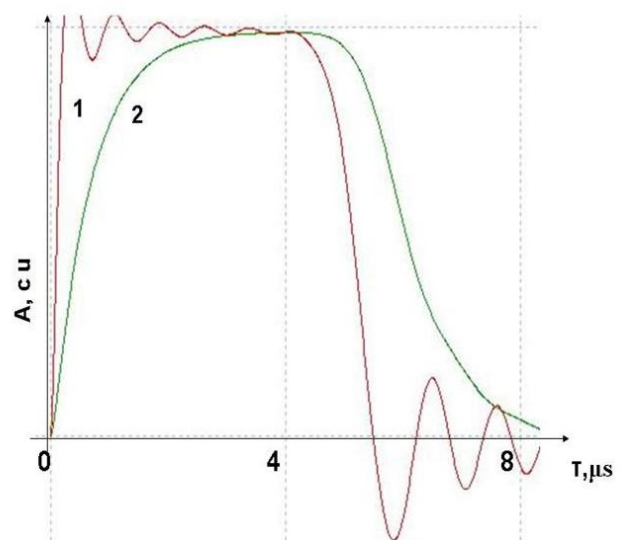

Fig. 2. Pulse transformer influence on pulse shape. 1 - without using a pulse transformer; 2 -using pulse transformer dissipation inductance $10 \mu \mathrm{H}$ dynamic transformer capacitance $-5 \mathrm{nF}$

Fig. 2 shows the voltage pulses from the forming line with and without a pulse transformer. The figure shows that the use of a pulse transformer leads to distortion of the pulse shape. So the scattering inductance and the inductance of the supply ends affect the formation of the pulse front, and the magnetization inductance affects the bevel of the peak of the voltage pulse.

Using calculations, we consider the influence of the leakage inductance of a pulse transformer on the shape of a voltage pulse under the condition of a coordinated load. Fig. 3,a shows voltage pulses for different scattering inductances. It can be seen from the figure that, with an increase in the scattering inductance, the pulse front is delayed. Fig. 3,b shows the dependence of the duration of the pulse front on the scattering inductance. It can be seen from the figure that the front duration can be reduced to $1 \mu \mathrm{s}$ by reducing the inductance of the supply ends, which is also included in the calculation. However, the most real duration of the pulse front will be $1.2 \ldots 1.5 \mu \mathrm{s}$.

The decrease in the peak of the pulse is influenced by the magnetization inductance of the pulse transformer. Fig. 4 shows the voltage pulses on the secondary winding of a pulse transformer for different magnetization inductances of a pulse transformer.

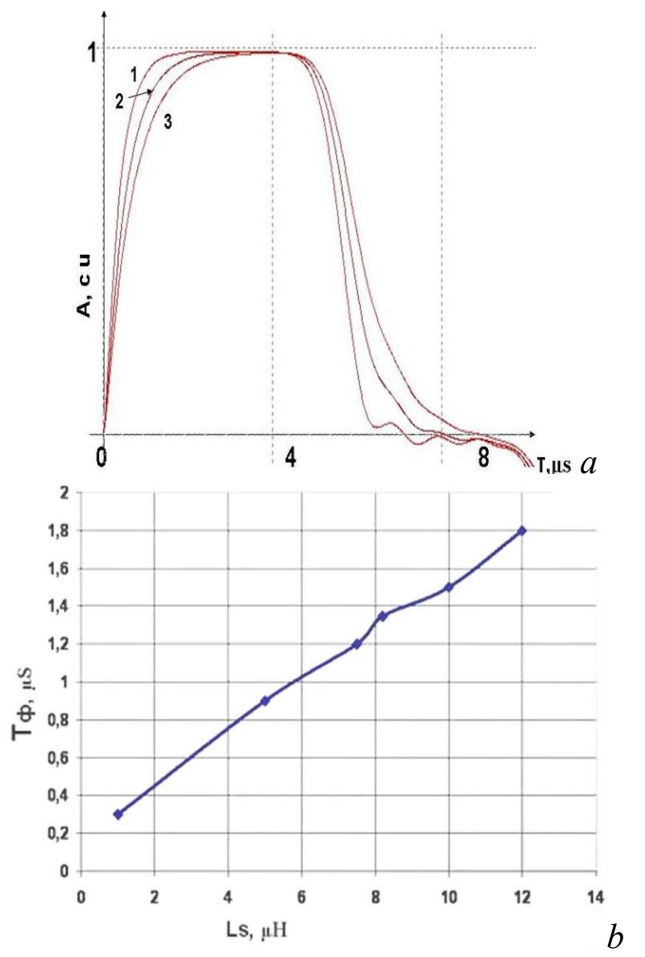

Fig. 3. Dependence of the rise time of the voltage pulse on the scattering inductance. $1-8 \mu \mathrm{H} ; 2-10 \mu \mathrm{H}$; $3-14 \mu \mathrm{H}$; dynamic transformer capacitance $-5 \mathrm{nF}$

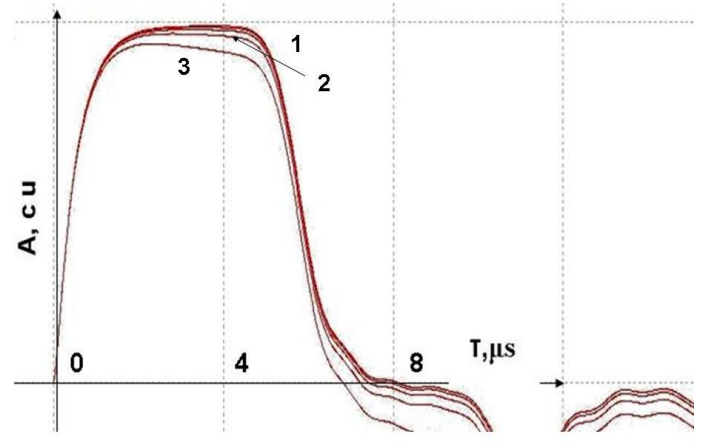

Fig. 4. The shape of the voltage pulse on the load at different magnetization inductances.

$$
1-4 \mathrm{mH} ; 2-2 \mathrm{mH} ; 3-0.5 \mathrm{mH}
$$

It can be seen from the figure that, with a decrease in the magnetization inductance, the slope of the pulse increases. The magnetization inductance is determined by the design parameters of the pulse transformer. It is possible to correct the peak of the voltage pulse by correcting the molding line, as well as by choosing the right demagnetization current.

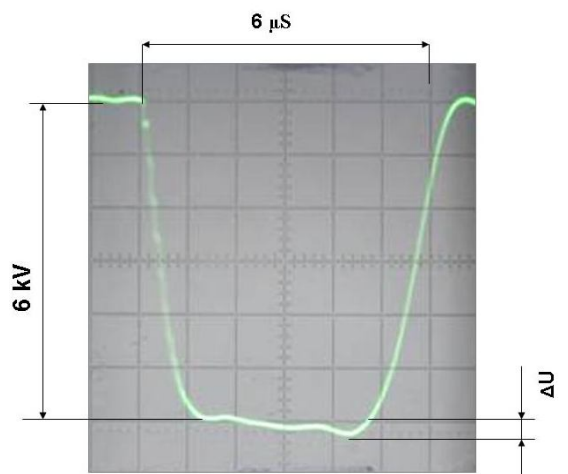

Fig. 5. Pulse at the output of the PFN. Re-correction 
Fig. 5 shows the voltage pulse at the output of the forming line whose shape was specially distorted. Thus, at the load, we obtain a voltage pulse with a uniform peak.

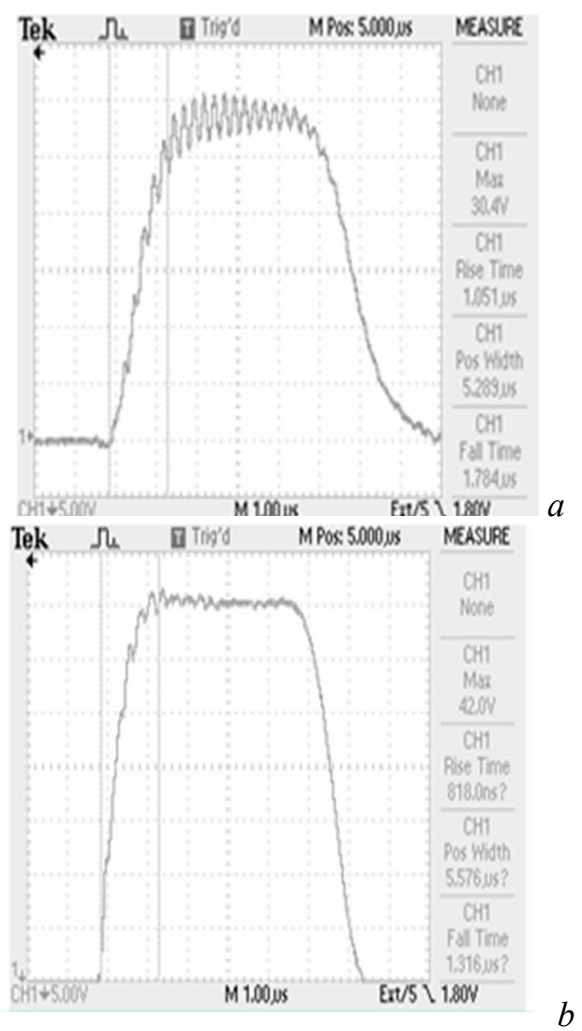

Fig. 6. Impulses of voltage at the load before and after setting the PFN

Fig. 6 shows the voltage pulse at the load with a tuned forming (b) line and without tuning (a). When adjusting the forming line, it was possible to increase the squareness coefficient from 0.6 to 0.8 , the pulse front was reduced to $1.15 \mu \mathrm{s}$.
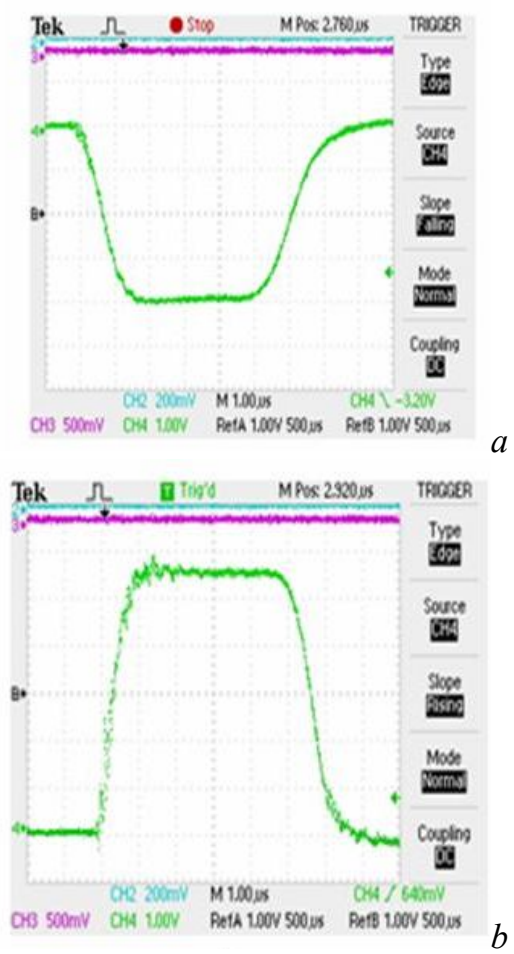
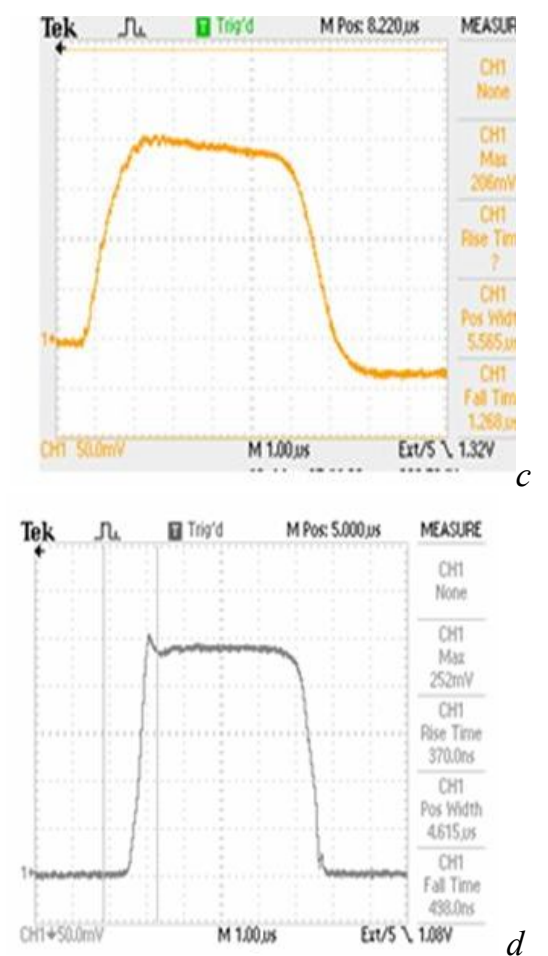

Fig. 7. Impulses of voltage at the load (a);

klystron current (b), and RF power before setting the pulse (c); shape and after (d)

Fig. 7 shows the pulses at the output of the process accelerator modulator. From the little one you can see, the main parameters of the pulse are stored: the pulse front is $1.2 \mu \mathrm{s}$, the pulse drop is $1.4 \mu \mathrm{s}$, the distance is $4 \mu \mathrm{s}$, the heterogeneity of the peak is $3 \mu \mathrm{s} 2 \%$. The coefficient of directness and impulse is $75 \%$ grade. Such parameters of the impulse were dominated by the way to adjust the formal line, and the impulse transformer.

The main components contributing to the energy efficiency of the installation are considered.

The main components contributing to the energy efficiency of the installation are considered.

The main contribution to the total power consumption is made by the power supply of the main elements of the modulator: the forming line, the transformer. Also, a large contribution of about $10 \%$ is made by the power consumed by the power of the solenoid. The remaining elements of the installation (vacuum pumps, measuring instruments) make a small contribution to the total power consumption.

Summing up the power values (see Fig. 7), taking into account the values of current and voltage at the load, we evaluated efficiency and the modulator. For existing installations, it will be $30 \ldots 35 \%$.

Thus, to increase the efficiency installations it is possible to adjust the voltage pulse on the load, create a focusing field using permanent magnets. It is also possible to switch to other circuit solutions (transition to a partial discharge).

\section{CONCLUSIONS}

The energy efficiency of high-voltage modulators in existing process accelerators is assessed. The losses in the main nodes of the modulator and the possibility of minimizing them are estimated. It is shown that with the correct setting and correction of the pulse, the formation 
efficiency increases significantly. Also, the efficiency of the installation can be increased by switching from a full discharge of the storage element to partial.

The efficiency of voltage pulse formation and the modulator efficiency is estimated.

\section{REFERENCES}

1. V.D. Bochkov, Yu.D. Dyagilev, Yu.D. Korolev. Powerful switchboards of current with LP of gas // DTE. 1998, № 5, p. 91-95.

2. V.I. Beloglazov, I.A. Chertyshchev, I.A. Chaika, A.I. Kosoi, D.A. Kapliy, V.P. Romasko, V.Yu. Titov, Yu.D. Tur. Design and exploitation powerful thyratron swith in modulators accelerators NSC KIPT // Problems of Atomic Science and
Technology. Series "Nuclear Physics Investigations”. 2016, № 3, p. 50-53.

3. V.I. Beloglazov, I.A. Chertyshchev, I.A. Chaika, A.I. Kosoi, V.P. Romasko, V.Yu. Titov, Yu.D. Tur. Development and improverment of switching stands of high-voltage LUE modulators // Problems of Atomic Science and Technology. Series "Nuclear Physics Investigations”. 2019, № 6, p. 35-38.

4. I.V. Kazarezov, A.A. Korepanov. Matching of the parameters of Pulse Forming Networks (PFN) and pulse transformers in quantizer circuits for power supply of high-power klystrons // Problems of Atomic Science and Technology. Series "Nuclear Physics Investigations”. 1999, № 4, p. 44-45.

Article received 10.03.2020

\section{ОЦЕНКА ЭНЕРГОЭФФЕКТИВНОСТИ МОДУЛЯТОРОВ ВЫСОКОГО НАПРЯЖЕНИЯ ЛУЭ}

\section{А.И. Косой, В.А. Мац, В.П. Ромасько, Ю.А. Титаренко, В.Ю. Титов, Д.В. Титов, Ю.Д. Тур, И.А. Чайка, И.А. Чертищев, Е.А. Ярошенко}

Проведена оценка энергоэффективности импульсных модуляторов технологических ускорителей в ННЦ ХФТИ. Исследовано влияние параметров импульсного трансформатора на импульс напряжения при нагрузке. Рассмотрены возможности повышения энергоэффективности установок. Проведены исследования потерь в высоковольтных импульсных модуляторах систем и показано, что основными элементами, требующими замены или улучшения, являются формирования линий и импульсных трансформаторов.

ОЦНКА ЕНЕРГЕТИЧНОЇ ЕФЕКТИВНОСТІ МОДУЛЯТОРІВ ВИСОКИХ НАПРУЖЕНЬ ЛПЕ

О.І. Косой, В.О. Мац, В.П. Ромасько, Ю.О. Тімаренко, В.Ю. Тітов, Д.В. Титов, Ю.Д. Тур, І.О. Чайка, I.О. Чертіщев, С.А. Ярошенко

Проведена оцінка енергоефективності імпульсних модуляторів технологічних прискорювачів у ННЦ ХФТІ. Досліджено вплив параметрів імпульсного трансформатора на імпульс напруги при навантаженні. Розглянуто можливості підвищення енергоефективності установок. Проведено дослідження втрат у високовольтних модуляторних системах і показано, що основними елементами, які потребують заміни або вдосконалення, є формування ліній та імпульсних трансформаторів. 